\title{
FISH FARMING IN THE MIDDLE AND FAR EAST
}

\author{
By Dr. C. F. HICKLING \\ Fisheries Adviser, Colonial Office
}

$\mathrm{F}$ ISH culture covers a wide field of activities by which the yield of fish from a given area of water can be increased by artificial means. It ranges from the stocking of natural waters with desirable species, and the encouragement of favourable environmental factors for their growth, accompanied perhaps by the elimination of undesirable species, to the construction of special ponds in which all the operations of animal husbandry are practised. It is with the latter aspect of fish culture, the true fish farming, that this article is concerned; although it is no more possible to give a complete account of fish farming than of any other type of farming in a single short article.

The yields obtained in fish farming are, of course, much greater than those from natural waters. Below are given some examples of yields of edible fish per acre per annum for certain natural waters, and for certain examples of fish farming.

\section{NATURAL WATERS}

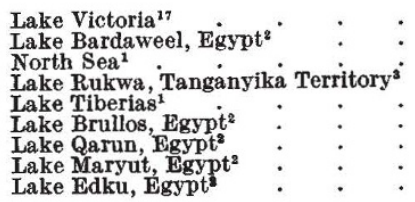

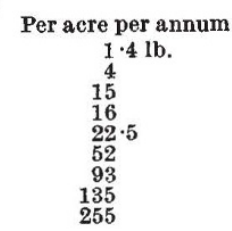

FIBH FARMS

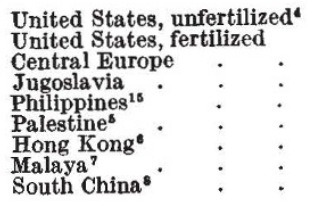

Per acre per annum 40-150 Ib. 200-400 168 327
$450-900$ 1200
$2000-4000$ 3500

It is true that the high yield of fish farms is got sometimes at considerable outlay in capital cost and recurrent costs, including the cost of fodder and fertilizer; but the exploitation of natural fisheries may also involve considerable capital and recurrent costs. Fishing eraft and gear have to be replaced frequently, but well-sited fish-ponds have stood for centuries in China.

Fish-ponds may be either freshwater or salt-water. Salt-water ponds are built or excavated in salt marshes, or in mangrove or nipah swamp, either facing the sea or on the shores of estuaries. They are sited so that the water in them can be renewed or emptied by opening sluices at spring tides. Saltwater fish-ponds reach their greatest development in the Philippines and the Netherlands East Indies. In the latter, the experts have contemplated pumping water into the fish ponds and so allowing the ponds to be sited independently of tide-levels. Their experience leads them to believe that the fish-ponds are profitable enough to bear the cost of pumping. Usually, in these salt-water fish-ponds the fish are not artificially fed, nor are the ponds fertilized; but, since they are usually on rich volcanic soil, the natural growth of plants suffices to give a good yield of fish which feed on them. Yet I am told that the Japanese fed the fish in their marine fish-ponds on Formosa, getting high yields, and the Netherlands East Indies authorities have experimented with fertilizers.
Freshwater fish-ponds are usually built or excavated in marshy ground, or on land of marginal use for agriculture. They may, in fact, be regarded as a step in the reclamation of such land. The marine fishponds of Java, also, are a stage in the extension of paddy cultivation. Such marine fish-ponds tend to become less and less saline, until they will grow rice; the seaward belt is then added to by taking in more mangrove, or by bunding in the silt which tends to form to the seaward side of such fish-ponds. Even where they are constructed on potential agricultural land, they do not necessarily compete with its agricultural use. They may be used to grow alternative water crops, such as water chestnut, and watercress and arrowhead for human consumption, or water lilies and water hyacinth for pig food. They may be used to grow rice or other irrigated crops. The accompanying photograph shows a corner of a fishpond at Tai Leong, in the Pearl River Delta of China, in which rice is growing. In this area alternate crops of paddy and fish may be taken, the paddy crop from February to June or July, and the fish crop from July to December and January. Fishponds fit in particularly well with a system of peasant small-holdings, as they can be run concurrently with a number of other activities, such as vegetable gardens and pig- and duck-raising.

Fish-ponds must, of course, be situated where they can be kept filled with water, and in lands where water is scarce there may be competition as between fish-ponds and irrigated crops. But Bertram ${ }^{5}$ points out that evaporation from a water surface is not necessarily greater than from a growing irrigated plant crop, and that fish must be regarded simply as an alternative crop, to be judged on its merits, having regard to current demand for food, whether animal or vegetable.

Some idea of the scale on which fish farming is arried on in the Far East may be got from Furnivall", who estimated that there were some 200,000 acres of marine fish-ponds and at least 100,000 acres of freshwater fish-ponds in the Netherlands East Indies. Hoffmann ${ }^{8}$ estimated that in six districts of the Kwangtung Province of China alone there were some 200,000 acres of fish-ponds. Frey ${ }^{15}$ states that, before the recent War, there were 60,000 hectares of marine fish-ponds in the Philippines.

The size both of the fish farms and of the individual ponds varies greatly. In Palestine, the individual fish farm may be more than 100 acres, with ponds as large as 15 acres or more. In the marine fish-ponds of Java, the individual ponds may be 6-7 acres in extent, and in the Philippines 5 acres. In Hong Kong the largest ponds I saw had an area of 10 acres on a farm of more than 60 acres. A few of the ponds I saw in the Pearl River Delta had an area of 3 acres, and at Shuihing on the West River, of 7 acres. But, in the Far East, most of the fish-ponds are small, of a size less than an acre. The depth is usually $3-5 \mathrm{ft}$.

In freshwater fish-ponds, the renewal of the water may depend simply on rainfall and local drainage and seepage. Where running water is available, it may be diverted into a channel, sometimes of considerable length, from which the ponds are fed by sluices. A cruder but effective arrangement is to put up a temporary dam in a nearby stream or ditch, whereby the water-level may be raised to the point when it will flow into the fish-ponds. In the Pearl River Delta, and to some extent in Hong Kong and Singapore, the water may be renewed by the action of the tides. When the rivers are in full flow after 


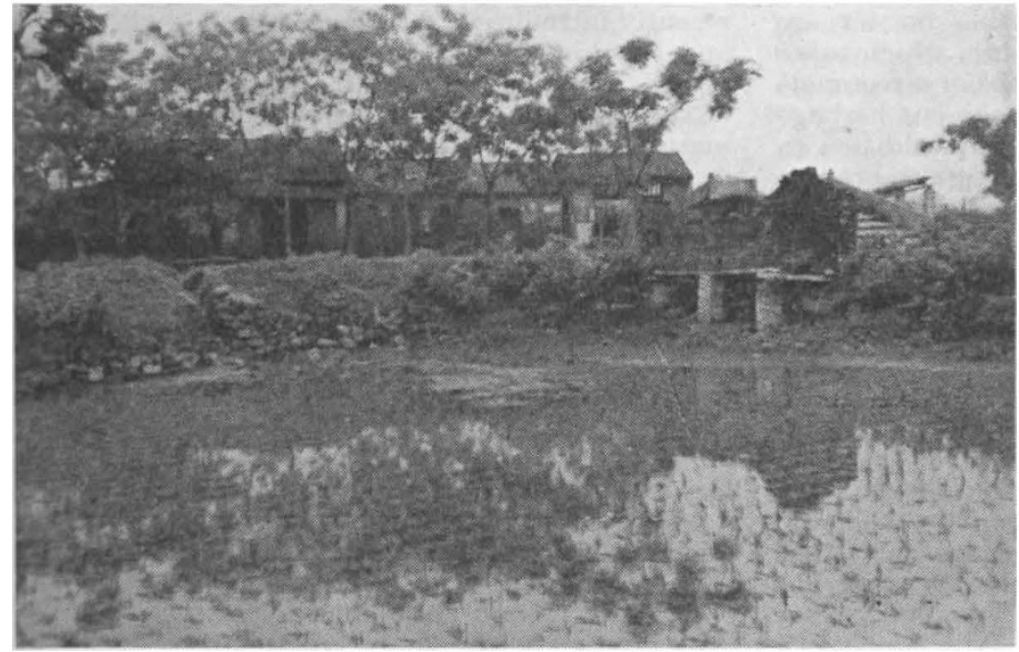

A fish-pond at tat leong, peart River Detta

whether natural or supplied by the fish-farmer, is fully used.

In the Javanese culture, the Gourami is a grass and vegetable feeder, the Nilem is a macroplanktonic feeder, the Tawes a bottom feeder and the carp a bottom feeder and general scavenger.

In the Chinese culture, the grass carp is a vegetable feeder, the silver carp a microplanktonic feeder, the big head a macroplanktonic feeder, the mud carp a bottom feeder, the common carp a general scavenger and the black carp a feeder on molluses and crustaceans. In Hong Kong the grey mullet is stocked in very large numbers in partial substitution for the mud carp.

The rate of stocking, and the

rains, the rising tide coming up the rivers may cause the level of the river to rise by many feet, and as the surface water, at all events, will be fresh, sluices are opened, or channels cut, to take the surface water into the ponds.

Where the ponds are embanked, they can be emptied through sluices; but, where they are excavated, they cannot be emptied by gravity. They may never be emptied, the bottom being cleaned by scraping with special long-handled scoops, or, in the case of small ponds, they may be emptied by treadle pumps. Where the ponds are never emptied, the water is freed from predatory fish and other harmful organisms by poisoning the water between each crop of fish.

\section{Species of Fish Used}

The most important species cultivated in marine fish-ponds is the salmon-herring, or milk-fish, Chanos chanos Forsk. ${ }^{13,14,15}$. But mullet also flourish in marine fish-ponds, and prawns, which breed freely in the ponds, are a valuable catch-crop. In Java, the aquarium escape Tilapia mossambica, an East African species, has been cultivated with success in the marine fish-ponds during and since the War, when the disruption of communications has prevented stocking with the fry of the Chanos. But Chanos also is a very adaptable species, which can easily be acclimatized so as to flourish in fresh water; it is being stocked in the inland waters of India ${ }^{10}$.

In the freshwater fish-ponds, some of or all the following species are stocked together in the same ponds.

\section{Palmstine}

Common carp (Cyprinus carpio Linn. ? Tench (Tinca tinca Linn.)

\section{JAVA}

Common carp

Gourami (Osphronemus olfax Blkr.) Tawes (Puntius javanicus Blkr.) Nilem (Osteochilus hasselti C.V.)
HONG KONG* Common carp Silver carp (Hypophthalmichthys molitrix Cuv, and Val.) Big head (Aristichthys nobilis Richardson) Black carp (Mylopharyngodon athiops Basilewsky) Mud carp (Cirrhina molitorella Cuv. and Väl.) Grey mullet (Mugil cephalus Linn.)

Where many species are stocked together, they are species of complementary feeding habits, and so chosen that all the available food in the pond, ratio of different species used, varies according to the productivity of the pond and the judgment of the farmer. But the grass carp and the mud carp are usually the chief species. As an average of a number of ponds seen by myself, and quoted by $\mathrm{Lin}^{6}$, the following is the composition of the communities in Chinese ponds per acre.

$\begin{array}{lllr}\text { Grass carp } & : & : & \mathbf{5 3 0} \\ \text { Big head } & : & : & 315 \\ \text { Silver carp } & : & : & 375 \\ \text { Common carp } & : & : & 35 \\ \text { Black carp } & : & : & \mathbf{2 1 2 5} \\ \text { Mud carp } & : & & \\ & & & 3640\end{array}$

This is a far higher rate of stocking than in Palestine, where the fattening ponds are stocked at a rate of about 1,000 fish per acre. The higher rate of stocking is probably due largely to the fact that many different species of complementary habits of life are stocked in the Far Eastern technique. The ratio of yield is about the same also, namely, about 1,200 lb. per acre per annum in Palestine and about 3,500 lb. per acre per annum in the Far East, showing that the rate of growth is just as good in spite of the heavier stocking.

It should be stressed again, however, that there is very great variation in the rate of stocking. For example, on a fish farm in the Pearl River Delta, one pond was stocked at the rate of 2,820 fish per acre, whereas a second pond, which had had for many years the benefit of a buffalo wallow on its banks, and was therefore much richer in plankton, was stocked at the rate of 3,720 fish per acre. Its yield was estimated at a rate of more than $5,000 \mathrm{lb}$. per acre per annum.

\section{Feeding}

The carp in Palestine are artificially fed, the ideal food being lupin seeds, though oil cake, such as cotton seed and peanut cake, have also been used, especially during the War. The growth of plankton is also stimulated by the application of farmyard manure and compost.

In the marine fish-ponds, the natural growth of algæ and other aquatic vegetation is usually the sole source of food $13,14,15$.

In the Far East, the ponds are manured to produce a rich plankton; but, for the grass carp, large quantities of cut grass which may be specially grown 
for the purpose, and other vegetable matter are thrown into a special feeding enclosure, which takes the form of a big ring of twisted ratans or a rectangle of floating bamboos. This prevents the cut herbage from being scattered over the pond. In addition to this, other food is provided. It may be rice-bran or copra waste, silkworms or silkworm fæces, peanut cake, and even termites.

According to Chen ${ }^{11}$, the grass carp feeds upon the cut herbage, and also on the artificial feeding materials supplied, while the big head and silver carp feed on the plankton generated by the manuring. The common carp and mud carp feed upon the artificial feeding materials, and the mud carp also on the bottom mud, enriched by the plankton and also by the fæces of all the other fish. The fæces of the grass carp consist of partly digested and finely divided vegetable matter; this also feeds the big head and silver carp. The few black carp eat the water snails, and, where these are abundant, extra black carp will be stocked.

Thus a very complete use is made of all natural and artificial food in the pond, and this is the reason (together with a high and comparatively uniform temperature) for the astonishing yields of these ponds. The expert fish culturist judges the productivity of his ponds by the colour and density of the plankton, and will add sufficient manure to maintain the optimum conditions. At the same time he will judge the acidity of the water by its taste.

\section{Stocking and Breeding}

Few of the species used in these techniques of fish culture are bred in the ponds. Indeed, the common carp, the Gourami, the Tawes and Nilem are the only fish which will so breed. In all other species, breeding will only take place in the wild, so that there is an extensive ancillary fry industry to supply the fish-ponds.

In the marine fish-ponds the Chanos chanos has never been known to spawn. The fry of this fish, and of the mullet, must be caught on the beaches and in the estuaries, and transplanted into the fattening ponds. The very valuable Chinese carps will only breed in certain rivers, of which the West River (Si Kiang) is the most important. In these rivers fry is caught in hundreds of millions in nets of ramie cloth spread out on stakes along the banks. The fry is sorted with immense skill, by passing through graded sieves, and by using the different oxygen requirements of the various species. For example, mixed fry may be allowed to stand in a limited amount of water until all are close to the surface in a struggle to get oxygen. Then a carefully judged quantity of fresh oxygenated water is added; at once those fry which need less oxygen leave the surface layer, and those remaining are skimmed off. In this way up to 90 per cent purity can be obtained. There are only a few fry culturists experienced enough to do this sorting accurately $\left(\mathrm{Lin}^{6}\right)$.

The very young fry, after sorting, are reared in special ponds, manured with cow dung and compost; they feed upon the plankton generated. When they grow larger, they may be fed with Australian flour shaken through a coarse cloth; for the young grass carp a small duckweed, Wolffia arrhiza, is specially grown. Finally, they are reared to the stage when they can be transported, from south China to Singa. pore, Java, Formosa and other markets. Mr. Le Mare, director of fisheries, Federation of Malaya, has recently introduced fry transport by air with success, and by this agency these valuable fry may, in the future, find a much wider market than at present.

The common carp will breed in captivity, and mature fish are placed in special spawning ponds, or in special enclosures in the fish-ponds. They are provided with bundles of brushwood on which to deposit the spawn, or with special frames containing teased-out coconut fibre. The frames, when covered with spawn, are removed and placed in hatching ponds.

The Gourami is also provided with similar frames, in which it builds its nest. In the case of the Nilem, small pools are connected with the main pond. The Nilem spawns at the entrance to these pools, so that the eggs are carried by a gentle current on to the gravelly bed of the pools, where they soon hatch (Furnivall').

\section{Fish-ponds and Disease}

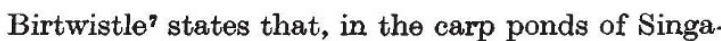
pore, mosquitoes are not produced if the ponds are in full cultivation, and Bertram ${ }^{5}$ had the same experience in Palestine. Sunier ${ }^{13}$ showed that the marine fish-ponds of Java were dangerous breeders of malaria-carrying mosquitoes; but, more recently, Overbeek and Stoker ${ }^{18}$ have shown how these marine fish-ponds, and also fresh water fish-ponds, have been made safe by appropriate clearance and drainage measures. In China I was told that the fish in the ponds deal effectively with mosquito larvæ. The chief prerequisite is that the pond shall be free of masses of weed, whether fixed or floating, in which mosquito larvæ can develop protected from the attacks of fish. Pielou is in Northern Rhodesia showed that the only specimens of the malariacarrying $A$. gambice and $A$. funestus found in the main dam at Chilanga, Northern Rhodesia, were respectively in a mat of floating debris, and among the semi-submerged grass at the margin of the dam, which is stocked with Tilapia Kafuensis and bluegill sunfish, Lepomis macrochira. On the other hand, in pools without fish, and in seepage ditches and puddles, these mosquitoes were frequent. Irvine ${ }^{12}$ states that Tilapias are effective against mosquitoes, and experience has shown that they are also excellent pond-fish. I did not hear of bilharzia being propa gated by fish-ponds; but the inclusion in the pond community of a few snail-eating fish, as in China, would guard against this danger.

In China, liver-fluke disease is conveyed by the eating of fish reared in ponds fertilized by raw nightsoil. The remedy for this would be not to use nightsoil as a manure for the ponds, or to use composted night-soil only, in which the heat of composting will have destroyed the young stages of the flukes.

\section{Conclusion}

The significance of fish farming as a technique does not seem to be widely understood, except in India, where great efforts are being made to propagate it. There are few countries, certainly in the tropics, which are so fortunately placed as to be able to get adequate supplies of fish from natural sources. Moreover, populations are growing, and industrial developments are calling for a higher standard of nutrition. Protein shortage has always been the bane of most tropical populations and, for a number of reasons, meat will not wholly supply the deficit. 
It is the policy of the Colonial Office to develop fish resources everywhere, and there is a vast field of work, in exploring and in improving, by experiment and precept, the natural fisheries, both fresh water and marine. But the product of the natural fisheries can be powerfully supplemented by the product of fish-ponds, especially where difficulties of transport and preservation stand in the way of meeting the requirements of the populations by fish from natural fisheries. There are big areas of marshy land, particularly in Africa and in the West Indies, which could be developed for fish farming, and fish farming could also be introduced wherever there is well-watered land undeveloped, or even in developed land as part of a mixed culture. Moreover, along the coasts there are many areas where marine fish-ponds could be laid out. The aim should be to make each community self-supporting for fish, or, still better, with a surplus to pass into the common supply.

The Colonial Office therefore plans to set up a research institute, on the scale of a first-class agricultural station, to study the fundamental processes underlying the high yields of fish-ponds, to study the genetics of fish and the physiology of breeding, and to get statistically controlled data of yields under a great variety of treatments. Here, also, fish culturists would be trained under experts.

The results of these fundamental researches would be applied, suitably modified, in each Colonial territory, and with communities of fish, preferably native fishes, best adapted to each.

${ }^{1}$ Bertram, C. K. Ricardo, Nature, 152, 415 (1943).

${ }^{2}$ Wimpenny, R. S., Report on Fisheries, Egypt (1928).

${ }^{3}$ Swynnerton, G. H., unpublished report on Lake Rukwa.

- Fishery Resources of the United States. Document 51, 79th Congress, 1st Session (Washington, 1945).

'Bertram, G. C. L., Empire J. Exp. Agric., 14, No. 56 (Oct. 1946).

${ }^{6}$ Lin, S. Y., J. Hong Kong Fisheries Res. Station, 1, No. 2 (1940).

"Birtwistle, W., Malayan Agric. J. (Aug. 1931).

${ }^{8}$ Hoffmann, W. E., Lingnan Univ. Sci. Bull., No. 5 (1934).

- Furnivall, W., "Fisheries in Netherlands Indies" (Burma Book Club, 1934).

${ }^{17}$ Chindambaram and Unny, Nature, 157, 375 (1946).

${ }^{11}$ Chen, T. P., Lingnan Univ. Sci. J., 13 (2), 275 (1934).

${ }^{12}$ Irvine, "Fishes of the Gold Coast"" (1948).

is Sunier, A. L. J., Treubia, 2, 157 (Sept. 1922).

14 Adams et al., Philippine J. Sci., 47, No. 1 (Jan. 1932).

${ }^{15}$ Frey, D. G., J. Mar. Res., 6, No. 3, 247 (1948).

${ }^{16}$ Pielou, D. P., Ann. Rept. Game and Tsetse Control Dept., N. Rhodesia (Lusaka, 1946).

${ }^{17}$ Worthington, E. B., Nature, 151, 353 (1943).

18 Overbeek, J. G., and Stoker, W. J., "Malaria in the Netherlands Indies and its Control" (Batavia:' Kolff and Co., 1937).

\section{MAX PLANCK MEMORIAL CEREMONY AT GÖTTINGEN}

A PRIL 23 of this year was the ninetieth anniversary of Max Planck's birth, and it had been the hope of his colleagues and admirers that the day might be the occasion of a simple festivity at which they could express their admiration and affection in the presence of the man in person. His death last October having prevented the realization of this wish, the Max-Planck-Gesellschaft zur Förderung der Wissenschaften (see later), the University of Göttingen, the Akademie der Wissenschaften of Göttingen and the Deutsche Physikalische Gesellschaft decided to celebrate the day by ceremonies devoted to the memory of Max Planck. Accordingly, on a bright spring day in the beautiful town of Göttingen, which fortunately is untouched by the hand of war, the character and achievements of the great man were fittingly celebrated by tributes in which appreciation of his scientific work and veneration for his personal qualities were equally balanced.

The first ceremony took place at 9 o'clock in the morning at his grave, marked by a simple stone, when wreaths were solemnly deposited by some of the foremost men of science in Germany, representing German universities, scientific societies and other bodies, and by representatives of certain scientific institutions of other lands. The British representatives were Sir Charles Darwin, representing the Royal Society; Prof. E. N. da C. Andrade, supported by Sir Robert Watson-Watt, representing the University of London; and Dr. B. K. Blount, representing the Research Branch of the Central Control Commission at Göttingen. Dr. Nordstrom represented the National Academy of Sciences of the United States and Prof. Otto Hahn laid a wreath on behalf of the Royal Swedish Academy. Many of the representatives spoke brief words of admiration of the great scientist. The occasion was deeply impressive. After a short interval the representatives proceeded to the Aula (Great Hall) of the University, where the main ceremony took place.

This was divided into two parts. The first consisted of brief addresses, delivered respectively by Prof. Otto Hahn, president of the Max-Planck-Gesellschaft zur Förderung der Wissenschaften; Prof. Hans Stille, vice-president of the Deutsche Akademie der Wissenschaften of Berlin, with which Planck was for so long prominently associated; Sir Charles Darwin, representing the Royal Society, of which Max Planck was a foreign member; and Prof. Hermann Dersch, representing the University of Berlin. A tribute from the Washington Academy of Sciences, written by Albert Einstein, was read by Prof. Hahn. The second part comprised three speeches in memory of Max Planck. Prof. Max von Laue spoke of the history, particularly the early history, of Planck's scientific work, laying stress on his handling of thermodynamic problems; Prof. Werner Heisenberg spoke particularly of the later developments of the quantum theory and of Planck's interest in recent work; Prof. Richard Becker dealt rather with the philosophical implications of Planck's work and with his human qualities. He introduced records of Max Planck's voice with striking effect. Throughout the ceremony, at which a large audience attended, the deep sincerity and controlled emotion of the speakers were evident, and the atmosphere was sustained by a simple and admirably chosen programme of music carried out by Karl Klinger, violinist, and Raimar Dahlgrün at the piano. Bach introduced the meeting, Brahms came between the two parts, and the last movement of Beethoven's Kreutzer sonata concluded the ceremony.

In the evening of the day of the ceremony an informal party ("Zwangloses Beisammensein") was given in a hall of the extensive premises of the Aerodynamisches Versuchsanstalt*, formerly devoted to aeronautical research for the German Government and now in the hands of the Research Branch of the Central Control Commission under Dr. B. K. Blount, to whose co-operation the party was due and to whose friendly efficiency the British visitors are much indebted. At this party various prominent German figures were present, including Otto Hahn, Lise Meitner, Max von Laue, Wermer Heisenberg, Ludwig Prandtl, R. W. Pohl, R. Becker, Erwin Meyer, E. Gruneisen, W. Meissner, J. Mattauch,

\footnotetext{
* Still known as 'AVA', although the first 'A' now indicates
} 